\title{
The Marketplace Variables in Successful and Unsuccessful NPD Projects in Technology Intensive Companies
}

\author{
Matti Haverila'
}

\begin{abstract}
We present an exploratory investigation of how managers conceptualize and perceive 'marketplace' variables in successful and unsuccessful New Product Development (NPD) projects, and explore the role that marketplace variables play in differentiating between successful and unsuccessful NPD outcomes. Limitations and future research directions are also discussed.

Our findings indicate that managers perceive the marketplace in multiple ways during the NPD process and also that differences exist in metric equivalence across successful and unsuccessful NPD projects. Also, although half of the marketplace variables are positively related to NPD success, managers in Finnish technology companies appear to attach higher relative importance to market attractiveness rather than market competitiveness variables. Marketplace variables appear to be less important than in the Korean and Chinese samples, and much more important than in the Canadian sample in the Mishra et al. study (1996), and similarly much more important than in the Cooper study (1979b).
\end{abstract}

Keywords: New product development (NPD); technology products; managerial conceptualization; marketplace variables.

\footnotetext{
I School of Business and Management. American University of Sharjah. Sharjah, United Arab Emirates, 26666. E-mail: mhaverila@aus.edu
} 


\section{Introduction}

Technology and research regarding new products play a significant role in most developed countries and particularly in the Finnish economy. The R\&D done and the financial resources used for research both by the private and public organizations in relation to the size of Finnish economy has increased continuously during last 30 years and stands at around $3.5 \%$ of GNP with total spending being about $5.8 \mathrm{~B} €$ in 2007 . At the same time this percentage in EU-25 is about $1.9 \%, 2.6 \%$ in United States and 3.1\% in Japan (Jiang, et al., 2006; Mohnen, 2005). Thus Finland can be regarded in relative terms as an R\&D intensive country in the OECD area. R\&D is a major competitive aspect for the Finnish economy (Ahola, 2006).

It is vitally important that the research process is efficient and as much as possible is known of all the variables, including the way managers conceptualize the marketplace variables affecting the success and failure of the new product development projects (Cooper, 1979a and b). Thus the purpose of the study is to investigate the ways in which marketing managers in the technology intensive companies in Finland conceptualize (or perceeive) the marketplace in successful and unsuccessful new product development (NPD) projects. The minimum requirement regarding the conceptualization is partial equivalence. Otherwise the comparison of the successful and unsuccessful marketplace variables has to be done with caution. In the extreme case a content respecification of the marketplace variables might be needed. The R\&D process has been under a lot of scrutiny by various researchers, but this aspect has been very little researched. These issues are important because of the vigor and role of R\&D in the global economy. This exploratory research is a part of a larger research project concentrating on the R\&D efforts of Finnish business-to-business (B2B) technology companies. We surveyed marketing managers at I3I Finnish companies. The analysis of 262 successful and unsuccessful products indicates that certain information acquired about the Finnish marketplace variables are highly correlated with new product outcomes.

\section{Theoretical Background}

The literature in the area of NPD success and failure has been comparatively extensive (Ernst, 2002) starting

ISSN: 07I 8-2724. (http://www.jotmi.org)

Journal of Technology Management \& Innovation (C) Universidad Alberto Hurtado, Facultad de Economía y Negocios approximately 30 years ago. The conclusion is that continuous development and market introduction of new products is an important determinant of constant company performance (Blundell, et al., 1999; Brockoff, 1999; Capon, et al., 1990; Cheney and Devinney, 1992; Urban and Hauser, 1993). As in the Mishra et al. article (1996), the Cooper framework (1979a) for new product success is used in this research project. According to the previous research the success of new products is based on environmental and controllable factors. This is consistent with the research carried out in this field (Cooper, et al., 1995; Henard, et al., 200I; Song and Parry, 1997a and b). Furthermore, the environmental factors relate to the setting in which a new product is developed and the controllable factors relate to the characteristics of new product activities that can be controlled by the firm.

\section{I. Market Environment Factors}

Broadly speaking the environmental factors include the following:

I. Characteristics of the marketplace.

2. Compatibility of the new product with the company's current skills and resources.

3. Descriptors of the new product venture.

Characteristics of the marketplace are typically not in the control of the management. The marketplace variables, however, have been linked with the new products success (Song and Parry, 1997b). These factors include issues like degree of price competition, presence of a dominant competitor, market size, market growth, the speed of acceptance of the new product and role of government in the marketplace. Myers and Marquis among others found out that most of the new product successes were marketderived (also called "market pull") (Myers and Marquis, 1969; Roberts and Burke, 1974). Cooper and Kleinschmidt (1987) indicated that market potential (or market attractiveness) together with market competitiveness are an integral part of the conceptual model of new product outcomes, and should have a positive effect on new product success. They furthermore indicated that the market potential construct consists of market size, market growth, customer need level for the product type, and importance of the product for the customer. Market 
competitiveness on the other hand included intensity of competition, degree of price competition, strength and quality of competitors' products, competitiveness of competitors' prices, strength of competitors' sales force/distribution system, and strength of competitors' service.

The market potential construct significantly correlated with seven of the II measures of success used by Cooper and Kleinschmidt (1987), and thus the market potential got partial support for the hypothesis that market potential is positively correlated with the new product success. These measures of success included items like profitability, payback period, market share, relative sales and profits among other things. The market competitiveness construct, however, did not correlate with any of the II measures of success, which according to Cooper and Kleinschmidt was a somewhat surprising result.

Zirger and Maidique (1990) indicated that there were two separate factors: large and growing market, and weak competitive environment. The large and growing market factor consisted of two variables, which were "Product was developed for a large market", and "Product was developed for a rapidly growing market". The weak competitive environment factor consisted of "Product was first to the market", and "Product was developed for a market with few strong competitors". Both variables for the two factors had very high factor loadings in the study, and correlated with new product success.

Montoya-Weiss and Calantone (1994) indicated in their meta-analysis that market environment factors were market potential, market competitiveness and environment. They indicated that some researchers reported non-significant and others significant results for the relation between market environment factors and new product success. They concluded that the overall results were moderately significant, but inconclusive. Their conclusion was, however, that there appeared to be a high degree of agreement among researchers concerning the importance of competitive nature of the market environment as a potential determinant of performance. Cooper (1985) indicated a potential reason for this surprising result as follows: "The reason for the market competitiveness being important, but not a significant determinant of performance is that the markets are so competitive because they are so lucrative, and thus the market attractiveness is well read by the competitors, and thus the end result is that the markets are lucrative and competitive at the same time. As a conclusion these positive and negative aspects cancel each out, and the performance is neither improved or decreased." Cooper furthermore (1979c) reports in another study regarding new product failures that the most common reason for new product failure is competitor's strong presence in the market. This has been confirmed by other studies (Song and Parry, 1997a; Zirger and Maidique, 1990). Finally, Yoon and Lilien (1985) indicated that new industrial product performance is affected by market growth, marketing rivalry and innovation rivalry.

Do the marketing managers in the high technology companies conceptualize the marketplace variables in the similar fashion than in the Cooper study (Cooper, 1979b)? Also how do the marketplace variables in this exploratory study differentiate successful and unsuccessful NPD projects in the technology intensive companies? A key point in performing this research is establishing conceptual equivalence regarding how managers conceptualize the success factors in NPD projects. Only if the managers conceptualize the marketplace factors in a similar fashion, the differences in managerial perceptions between successful and unsuccessful NPD projects can be compared (Cheung and Chan, 2002). A minimum requirement is achieving at least a partial conceptual equivalence (Byrne and Watkins, 2003).

On the basis of this the following hypothesis is set for this exploratory study:

Proposition I: The marketing managers perceive there to be multiple marketplace factors affecting the success of NPD projects.

Proposition 2: The marketing managers conceptualize the marketplace factors in a similar fashion in successful and unsuccessful NPD projects.

This study concentrates on the marketplace related factors only, and thus the other factors (Compatibility of the new product with the company's current skills and resources, and Descriptors of the new product venture) are beyond the scope of this research. 


\section{Methodology}

\section{I. Sample}

When determining the sample the information sources of Statistics Finland (http://www.stat.fi/index_en.html) are used. The original sample population included companies in high technology and medium technology industries (Table I). A typical definition of a technology company is based on the amount of financial resources used in relation to the sales of the company. More specifically OECD (2005) states that: "An industrial sector is defined as high-technology according to its overall $R \& D$ intensity (sum of direct and indirect). The direct intensity corresponds to the ratio of $R \& D$ expenditure to value added for each sector and country. For indirect intensity, embodied technology ( $R \& D$ expenditure) in intermediate and capital goods purchased should be taken into account."

\begin{tabular}{|l|c|c|}
\hline \multicolumn{1}{|c|}{ Industry } & \multicolumn{2}{c|}{ Sample population } \\
\hline High technology industries & \# of firms & \% of sample \\
\hline Medical drugs (244)* $)^{*}$ & 2 & 4,54 \\
\hline Electronic and communications equipment (32I, 322)* & 62 \\
\hline Medium high technology industries & 8 & 6,15 \\
\hline Chemical products (24, not 244) & 60 & 46,15 \\
\hline Machinery and equipment (29, not 297I) & 13 & 10,00 \\
\hline Electro-technical machinery and equipment (297I, 3I, 323)* & 8 & 6,15 \\
\hline Instruments and fine mechanics (33)* & 4 & 3,08 \\
\hline Transportation vehicles (34, 352)* & 30 & 23,08 \\
\hline Information not available & 13 I & 100 \\
\hline Total & & \\
\hline
\end{tabular}

* Statistics Finland 2002 classification number

Table I. Sample population.

\subsection{Measurement and Questionnaire Development}

In order to study the marketplace variables (Table 2) present in the NPD projects in Finland, we used a questionnaire consisting of 16 statements developed by Cooper (1979b). The author prepared the questionnaire with the help of an English language instructor residing in Finland. The language instructor created the preliminary version and the final version was developed through multiple iterations to make sure that there was a high degree of consistency between the original English and final Finnish language version.
We asked the marketing managers to select two typical NPD projects introduced by their companies, one of them being a clear commercial success and the other being a commercial failure as perceived by them. Each manager indicated on a 7-point scale $(I=$ strongly disagree, $7=$ strongly agree) how well each statement described the selected products. In addition, the marketing managers were asked to define the degree of success for the successful and unsuccessful products separately with a 7point scale ( $I$ = very unsuccessful, $7=$ very successful). 


\begin{tabular}{|c|c|}
\hline \multirow{7}{*}{ Market competitiveness } & I. Competitors' frequently introduced new products \\
\hline & 2. Existence of dominant competitor \\
\hline & 3. Degree of price competition \\
\hline & 4. Degree of satisfaction with competitors' products \\
\hline & 5. Degree of loyalty to competitors' products \\
\hline & 6. Our new product had a monopoly in the market \\
\hline & 7. Degree of competition \\
\hline \multirow{9}{*}{ Market attractiveness } & 8. Existence of potential demand only (no actual market) \\
\hline & 9. Degree to which users' needs change quickly in the market \\
\hline & 10. Extent of role of government in the marketplace \\
\hline & II. Market size \\
\hline & 12. Existence of mass market (as opposed to one or few customers) \\
\hline & 13. Degree of need for products in product class \\
\hline & 14. Market growth \\
\hline & 15. The global economic situation was favorable \\
\hline & 16. The speed of acceptance of the new product \\
\hline
\end{tabular}

Table 2. Marketplace variables.

\subsection{Methodology}

Various researchers have carried out research regarding the factors affecting the success and failure of new products. The scope and objectives of this exploratory research is to investigate the way managers conceptualize the marketplace, and then to compare the managerial perceptions regarding marketplace variables in successful and unsuccessful NPD projects. The research project is exploratory in nature. The JMP I-2-3 software package by SAS is used for statistical analysis.

In order to be able to proceed with factor analysis, correlation matrix between all the variables was computed separately for successful and unsuccessful NPD responses. If the correlation matrix includes multiple correlations above 0.3 (Hair, et al., 2006), the data can be deemed to be suitable for factor analysis. Also the use exploratory factor analysis (EFA) is appropriate if there is no previous knowledge of the number, structure and dimensionality of marketplace variables in previous research of NPD projects in technology companies (Anderson and Gerbing, 1988). Unidimensionality is necessary for reliability analysis and construct validation (Churchill and lacobucci, 2005; Hair, et al., 2006). EFA is also helpful with construct metric equivalence, i.e. to investigate if the market place variables produce diverse factor structures in successful and unsuccessful NPD projects.
The variable structure was analyzed separately for successful and unsuccessful NPD projects. The principal components (PC) Varimax rotation, which is a criticismfree and thus a common rotational method, was used as the factoring method since the objective of the research was data reduction to a smaller number of variables. In addition, high loadings in the factors are likely when the Varimax rotation is used (Hair, et al., 2006) indicating that a clearer separation of factors is evident, which makes the interpretation of the factors easier (Costello and Osborne, 2005; Kim and Mueller, 1978).

Scree plots and Eigen values were also investigated in order to make sure that the number of factors is mainly responsible for variation in the data (Tabachnick and Fidell, $200 \mathrm{I}$ ). For Eigen values, the Kaiser criterion value 1.00 was used to determine the number of factors. The variance explained by the factor solution was also calculated with an objective level of 60 percent or more of total variance, which has been discovered to be satisfactory for a factor solution in social sciences (Hair, et al., 2006). Diekhoff (1992) and Heck (1988) regard 50 percent of total variance explained as the threshold.

Since there were $|3|$ observations, the threshold factor loading level for a variable was set at 0.50 (Hair, et al., 2006). Items with loadings of less than 0.50 on any factor or with loadings greater than 0.50 on more than one 
factor were dropped from consequent analysis (Hair, et al., 2006). Communality measures were also studied as part of the factor analysis and variables with communalities less than 0.50 were dropped from further analysis (Hair, et al., 2006). A communality of under 0.50 signifies that less than half of the variance in the item has been taken into account in identifying the latent construct.

Finally, we calculated correlation coefficients between the marketplace variables and the outcome of the new product development project, and a paired comparison t-test was used to test the significance of differences between successful and unsuccessful NPD projects. A significant paired comparison t-test on a variable implies that the mean rating for that variable is significantly different between successful and unsuccessful NPD projects. Key assumptions in the paired t-test are that the data are from the same subject or alternatively from a corresponding subject, and are taken from a population with a normal distribution. The normality of the distribution was measured with the Shapiro-Wilk test $(p<0.05)$.

\section{Results and Discussion}

\section{I. Descriptive Statistics}

As indicated above the marketing managers were asked to define the degree of success of both the successful and unsuccessful product as perceived by them with a 7-point scale $(I=$ very unsuccessful, $7=$ very successful $)$. The means and standard deviations to this question were 5.56
$(0.98)$ and $3.00(1.12)$ respectively indicating a significant difference $(<0.000)$.

The correlations between the marketplace variables, as well as the means and standard deviations of the variables in successful and unsuccessful NPD projects are presented in tables 3 and 4 . Both correlation matrices include plenty

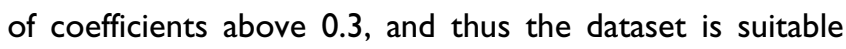
for factoring. The Bartlett test of sphericity, which tests if the correlation matrix is an identity matrix indicating inappropriateness of the factor model, was significant, and the Kaiser-Meyer-Olkin measure of sampling adequacy, which tests whether the partial correlations among variables are small, was greater than 0.60 . Inspection of the anti-image correlation matrix (negative value of the of the partial correlation) revealed that all the measures of sampling adequacy were above the acceptable level of 0.50 (Hair, et al., 2006).

\subsection{Exploratory Factor Analysis of the Market Environment Factors}

The factor analyses performed included several iterations, and as a consequence of them the variables "Extent of role of government in the marketplace" (variable 10), and "The global economic situation was favorable" (variable 15) were removed because they did not conceptually fit to any of the factors. In addition to the lack of conceptual fit these variables suffered of low communality values. The results of the final EFA iteration are presented in the following tables 5 and 6 .

\begin{tabular}{|l|l|c|c|c|c|c|}
\hline \multirow{2}{*}{$\#$} & \multicolumn{1}{|c|}{ Variable } & Commu- & \multicolumn{4}{|c|}{ Tentative Factor } \\
\cline { 4 - 7 } & & $\begin{array}{c}\text { Com- } \\
\text { nality }\end{array}$ & $\begin{array}{c}\text { Strong } \\
\text { peti- } \\
\text { product- } \\
\text { tion } \\
\text { market } \\
\text { position }\end{array}$ & $\begin{array}{c}\text { Degree of } \\
\text { competition } \\
\text { in growing } \\
\text { market }\end{array}$ & $\begin{array}{c}\text { Large } \\
\text { mass } \\
\text { market }\end{array}$ \\
\hline I & $\begin{array}{l}\text { Competitors' frequently introduced new } \\
\text { products }\end{array}$ & 0.482 & 0.386 & 0.140 & 0.266 & -0.492 \\
\hline 2 & Existence of dominant competitor & 0.656 & 0.798 & 0.128 & -0.000 & -0.054 \\
\hline 3 & Degree of price competition & 0.568 & 0.745 & -0.076 & -0.031 & -0.073 \\
\hline 4 & $\begin{array}{l}\text { Degree of satisfaction with competitors' } \\
\text { products }\end{array}$ & 0.532 & 0.633 & 0.202 & 0.027 & 0.299 \\
\hline 5 & $\begin{array}{l}\text { Degree of loyalty to competitors' } \\
\text { products }\end{array}$ & 0.611 & 0.739 & -0.012 & 0.001 & 0.255 \\
\hline 6 & $\begin{array}{l}\text { Our new product had a monopoly in the } \\
\text { market }\end{array}$ & 0.672 & -0.015 & 0.815 & -0.017 & 0.088 \\
\hline
\end{tabular}




\begin{tabular}{|l|l|c|c|c|c|c|}
\hline 7 & Degree of competition & 0.590 & 0.152 & -0.146 & 0.738 & -0.029 \\
\hline 8 & $\begin{array}{l}\text { Existence of potential demand only (no } \\
\text { actual market) }\end{array}$ & $0.45 \mathrm{I}$ & -0.263 & 0.244 & 0.567 & 0.032 \\
\hline 9 & $\begin{array}{l}\text { Degree to which users' needs change } \\
\text { quickly in the market }\end{array}$ & 0.612 & 0.586 & 0.246 & -0.452 & -0.060 \\
\hline II & Market size & 0.532 & 0.228 & 0.192 & 0.254 & 0.615 \\
\hline 12 & $\begin{array}{l}\text { Existence of mass market (as opposed to } \\
\text { one or few customers) }\end{array}$ & 0.697 & 0.104 & 0.286 & 0.057 & 0.774 \\
\hline I3 & $\begin{array}{l}\text { Degree of need for products in product } \\
\text { class }\end{array}$ & 0.660 & 0.130 & 0.754 & 0.09 I & 0.256 \\
\hline I4 & Market growth & 0.642 & -0.044 & 0.390 & 0.660 & 0.225 \\
\hline 16 & $\begin{array}{l}\text { The speed of acceptance of the new } \\
\text { product }\end{array}$ & 0.637 & 0.145 & 0.774 & 0.116 & 0.050 \\
\hline & Eigen value & & 3.42 & 2.43 & 1.38 & 1.10 \\
\hline & Variance explained (\%) & 24.4 & 17.3 & 9.9 & 7.9 \\
\hline & Cumulative (\%) & 24.4 & 41.7 & 51.6 & 59.5 \\
\hline & Cronbach alpha & 0.778 & 0.755 & 0.516 & 0.328 \\
\hline
\end{tabular}

Table 5. Rotated factor pattern in successful NPD projects (excl. variables "Extent of role of government in the marketplace", and "The global economic situation was favorable") *)

In the case of successful NPD projects there were 4 products". All communalities, except "Competitors' factors whose Eigen values exceeded the threshold level of frequently introduced new products", and "Existence of 1.0. All variables loaded above the threshold level of \pm 0.50 , potential demand only (no actual market)" exceeded the except 'Competitors' frequently introduced new 0.50 level for sufficient explanation.

\begin{tabular}{|c|c|c|c|c|c|c|}
\hline \multirow[b]{2}{*}{ \# } & \multirow[b]{2}{*}{ Variable } & \multirow[b]{2}{*}{$\begin{array}{c}\text { Commu- } \\
\text { nality }\end{array}$} & \multicolumn{4}{|c|}{ Tentative Factor } \\
\hline & & & $\begin{array}{l}\text { Com- } \\
\text { petition }\end{array}$ & $\begin{array}{l}\text { Large } \\
\text { mass } \\
\text { market }\end{array}$ & $\begin{array}{c}\text { Product } \\
\text { acceptance } \\
\text { in growing } \\
\text { market }\end{array}$ & $\begin{array}{c}\text { No } \\
\text { actual } \\
\text { market }\end{array}$ \\
\hline I & $\begin{array}{l}\text { Competitors' frequently introduced } \\
\text { new products }\end{array}$ & 0.631 & 0.596 & 0.024 & 0.273 & 0.447 \\
\hline 2 & Existence of dominant competitor & 0.675 & 0.724 & 0.378 & -0.090 & 0.014 \\
\hline 3 & Degree of price competition & 0.578 & 0.753 & 0.094 & 0.023 & 0.045 \\
\hline 4 & $\begin{array}{l}\text { Degree of satisfaction with } \\
\text { competitors' products }\end{array}$ & 0.610 & 0.695 & -0.079 & 0.230 & -0.261 \\
\hline 5 & $\begin{array}{l}\text { Degree of loyalty to competitors' } \\
\text { products }\end{array}$ & 0.622 & 0.779 & 0.081 & 0.055 & -0.074 \\
\hline 6 & $\begin{array}{l}\text { Our new product had a monopoly in } \\
\text { the market }\end{array}$ & 0.580 & 0.198 & 0.615 & 0.175 & 0.362 \\
\hline 7 & Degree of competition & 0.534 & 0.359 & -0.124 & 0.624 & -0.002 \\
\hline 8 & $\begin{array}{l}\text { Existence of potential demand only (no } \\
\text { actual market) }\end{array}$ & 0.769 & -0.246 & 0.013 & -0.009 & 0.842 \\
\hline 9 & $\begin{array}{l}\text { Degree to which users' needs change } \\
\text { quickly in the market }\end{array}$ & 0.686 & 0.726 & 0.314 & -0.087 & -0.227 \\
\hline
\end{tabular}




\begin{tabular}{|c|l|c|c|c|c|c|}
\hline II & Market size & 0.683 & 0.158 & 0.807 & 0.046 & -0.075 \\
\hline 12 & $\begin{array}{l}\text { Existence of mass market (as opposed } \\
\text { to one or few customers) }\end{array}$ & 0.740 & 0.075 & 0.852 & 0.093 & 0.015 \\
\hline 13 & $\begin{array}{l}\text { Degree of need for products in product } \\
\text { class }\end{array}$ & 0.701 & 0.124 & 0.704 & 0.435 & -0.037 \\
\hline 14 & Market growth & 0.664 & -0.100 & 0.374 & 0.717 & 0.008 \\
\hline 16 & 0.636 & -0.030 & 0.232 & 0.759 & 0.070 \\
& $\begin{array}{l}\text { The speed of acceptance of the new } \\
\text { product }\end{array}$ & & 3.89 & 2.27 & 1.32 & 1.16 \\
\hline & Eigen value & 27.8 & 16.2 & 9.5 & 8.3 \\
\hline & Variance explained (\%) & 27.8 & 44.0 & 53.5 & 61.8 \\
\hline & Cumulative (\%) & 0.828 & 0.801 & 0.579 & 1.000 \\
\hline
\end{tabular}

Table 6. Rotated factor pattern in unsuccessful NPD projects (excl. variables "Extent of role of government in the marketplace", and "The global economic situation was favorable") *)

The results of the final iteration for the unsuccessful NPD projects can be viewed as good from the factor analysis point of view. All variables load above are very close to the threshold level of \pm 0.50 . All communalities exceeded the 0.50 level for sufficient explanation. In the final iteration the Cronbach alpha was calculated to check the correlation between the variables in the various factors.

It is noteworthy in the case of successful NPD projects that the variable "Competitors' frequently introduced new products" had a nearly significant, but negative factor loading for the factor "Large mass market". This is also makes sense from the conceptual point of view, and therefore it was decided that this variable will be included in the factor, and no more iterations were necessary. Furthermore, a low communality of 0.482 of the variable "Competitors' frequently introduced new products", and the low communality of 0.45 I (table 5 ) of the variable "Existence of potential demand only (no actual market)" seem low but may be meaningful if the variable is contributing to a well-defined factor. What is critical is not the communality coefficient as such, but rather the extent to which the variable plays a role in the interpretation of the factor.

\subsection{Comparison of Marketplace Variables in Successful and Unsuccessful NPD Projects}

The analysis of the data done here follows the approach found in literature (Cooper, 1979a; Cooper \&
Kleinschmidt, 1987; Mishra, et al., 1996) and was also used in the first part of this research (Haverila, 2009).

The means of successful and unsuccessful products for the environmental factors are in table 7. Table 7 includes 14 statements in total, which illustrate the role of marketplace related variables for the new product success. The table does not include the variables "Extent of role of government in the marketplace", and "The global economic situation was favorable" because they were removed during the EFA iterations. The marketplace variables in table 7 were divided into two categories, which were market competitiveness and market attractiveness (Cooper, 1979a; Mishra, et al., 1996).

Before measuring the significant differences between the successful and unsuccesful cases, the normality of the variable distributions were measured with Shapiro-Wilk test so that significance level for $P$ was set at 0.05 (Hair, et al., 2006) and it was discovered that all distrubitions are normal. Not all differences between successful and unsuccessful products in table 7 were significant on the basis of the paired t-test however. Only one of the factors, "Strong product-market position", had a significant positive correlation $(0.44 ; p<0.000)$ with success in successful NPD projects. All other correlations were insignificant. 


\begin{tabular}{|c|c|c|c|}
\hline \multirow{2}{*}{ Market competitiveness } & \multicolumn{2}{|c|}{ Mean score } & \multirow{2}{*}{$\begin{array}{c}\text { Difference } \\
\text { score }\end{array}$} \\
\hline & Success & Failure & \\
\hline I. Competitors' frequently introduced new products & 4.02 & 3.47 & $-0.55^{*}$ \\
\hline 2. Existence of dominant competitor & 4.47 & 4.28 & -0.19 \\
\hline 3. Degree of price competition & 4.42 & 4.51 & 0.09 \\
\hline 4. Degree of satisfaction with competitors' products & 4.35 & 4.46 & 0.11 \\
\hline 5. Degree of loyalty to competitors' products & 4.22 & 4.47 & 0.25 \\
\hline 6. Our new product had a monopoly in the market & 3.82 & 2.55 & $-1.27^{*}$ \\
\hline 7. Degree of competition & 4.87 & 4.72 & -0.15 \\
\hline \multicolumn{4}{|l|}{ Market Attractiveness } \\
\hline $\begin{array}{l}\text { 8. Existence of potential demand only (no actual } \\
\text { market) }\end{array}$ & 5.69 & 3.58 & $-2.11 *$ \\
\hline $\begin{array}{l}\text { 9. Degree to which users' needs change quickly in the } \\
\text { market }\end{array}$ & 3.72 & 3.61 & -0.11 \\
\hline II. Market size & 4.94 & 3.68 & $-1.26 *$ \\
\hline $\begin{array}{l}\text { 12. Existence of mass market (as opposed to one or } \\
\text { few customers) }\end{array}$ & 4.99 & 3.55 & $-1.44 *$ \\
\hline 13. Degree of need for products in product class & 5.56 & 3.46 & $-2.10^{*}$ \\
\hline 14. Market growth & 4.59 & 3.25 & $-1.34^{*}$ \\
\hline 16. The speed of acceptance of the new product & 5.31 & 2.82 & $-2.49 *$ \\
\hline
\end{tabular}

Table 7. Impact of market competitiveness and attractiveness variables describing the marketplace on new product success.

\section{Discussion and Implications}

One of the implications of this research is that the managers perceived there to be multiple factors in the marketplace affecting the success of the NPD projects (tables 6 and 7). This was the case both in the successful and unsuccessful NPD projects. Thus hypothesis $I$ is supported. This has been found to be the case in the previous research (Cooper, 1979a; Montoya-Weiss and Calantone, 1994; Song and Parry, 1997a; Yoon and Lilien, 1985; Zirger and Maidique, 1990). The difference is, however, that the Cooper study discovered there to be two factors (market potential and market competitiveness) while there were 4 factors in this study both in the successful and unsuccessful NPD projects. This implies that the marketing managers in Finnish high technology companies perceive the marketplace to be more complex than the respondents in the Cooper study, which included more broad based and well established industries in its sample (automotive components, chemicals, computer equipment, food and packaging equipment etc.). This is an expected finding since the market of high technology products has been characterized to be turbulent in nature (Mohr, et al., 2004; Mohr, 1996; Gardner, et al., 2000; Wang, 2007). 
The exploratory factor analysis (EFA) iterations indicated that there is some degree of equivalence in the factor formation between the successful and unsuccessful NPD projects. The differences in factor formation, however, are quite strong indicating that the marketing managers conceptualize the marketplace variables quite differently. Therefore making comparisons regarding the perceptions of marketing managers of successful and unsuccessful NPD projects should be done with caution.

The factor "Competition" appeared as a strong factor in all iterations irrespective whether the NPD project was regarded to be successful or unsuccessful. The Cronbach alpha was also very high both in the successful (0.778) and unsuccessful (0.828) NPD projects, and exceeded the threshold level 0.700 set by Nunally (1972). This is consistent with previous research (Cooper, 1979a; Montoya-Weiss and Calantone, 1994; Song and Parry, 1997a; Yoon and Lilien, 1985; Zirger and Maidique, 1990).

Another factor, which seemed to appear throughout all iterations, was "Large mass market", which again is consistent with previous research (e.g. Hoffman et al., 1998). The factor formation was, however, slightly different in the case of successful and unsuccessful NPD projects. In both successful and unsuccessful NPD projects the factor consisted of the variables "Market size", and "Existence of mass market". The unsuccessful NPD projects included in addition to these two variables also variables "Degree of need for products in product class", and "Our product has a monopoly in the market". In other words the managers in the unsuccessful cases perceived that the variables "Market size", and "Existence of mass market" are not sufficient, and support by the variables "Degree of need for products in product class", and "Our product has a monopoly in the market" was needed. In the last iteration the variable "Competitors' frequently introduced new products" somewhat surprisingly did not load into the "Competitors" factor in the case of successful products, but it loaded in the "Large mass market" factor with a negative -0.492 loading. This in fact makes sense from the conceptual point of view. Due to this fact, and the closeness to the 0.50 threshold level, it was decided that the variable "Competitors' frequently introduced new products" was not dropped from the last factor analysis. It can be said that the factor "Large mass market" contributes to the success of NPD projects only if the competitors' are not introducing new products on a frequent basis. The Cronbach alpha was 0.328 in the successful and $0.80 \mathrm{I}$ in unsuccessful NPD projects. The threshold level 0.700 set by Nunally (1972) was not exceeded in the successful NPD cases. A low Cronbach alpha value was expected, however, because one of the variables (Competitors' frequently introduced new products) had a negative loading. If the variable "Competitors' frequently introduced new products" would be dropped on the basis of the low communality value (0.482), the factor solution would have improved so that the factor "Large mass market" would only have included the variables "Market size", and "Existence of mass market". In this case the last two variables expectedly had a high correlation (0.46). The interpretive power of the factor would have, however, decreased, and thus the variable "Competitors' frequently introduced new products" was not dropped.

One could say on the basis of the two factors "Competition", and "Large mass market" that there is almost full equivalence in the way the managers conceptualize these two factors in successful and unsuccessful NPD projects. This is a minimum requirement to be able to carry out subsequent multivariate analysis when comparing the factors affecting the success of the successful and unsuccessful NPD projects. As such the results here are interesting and useful when developing theory that will potentially lead to a measurement model, which can be tested with a confirmatory factor analysis (CFA) (Hair, et al., 2006).

The formation of the two remaining factors is, however, more fuzzy. In the successful NPD projects the third factor could be named as "Strong product-market position", because it consists of the variables "Our new product had a monopoly in the market", "The speed of acceptance of the new product", and "Degree of need for products in product class". From the conceptual point of view this factor appears to be sound. The Cronbach alpha in this case was 0.755 , which exceeds to threshold level established by Nunally (1972). In the case of unsuccessful NPD projects the third factor includes variables "The speed of acceptance of the new product", "Market growth", and "Degree of competition". This factor could be named as "Product acceptance in a growing competitive market". Again this can be regarded as conceptually sound, but different than in the successful 
NPD projects. The Cronbach alpha in this case was 0.579, which did not exceed the threshold level established by Nunally (1972). This could be explained by the slightly lower factor loadings than in the first two factors, and also by the fact that a fewer number of variables (3) loaded into this factor. It is noteworthy that the Cronbach alpha is dependent not only on the magnitude of the correlations among variables, but also on the number of variables in the scale. Thus if the average correlation between variables is the same, the Cronbach alpha value can be increased simply by adding more variables (Streiner and Norman, 1989).

The fourth factor in the case of successful NPD projects consists of the variables "Degree of competition", "Market growth", and "Existence of potential demand only (no actual market)". This factor could be named as "Degree of competition in growing market". The Cronbach alpha in this case was 0.516 , which did not exceed the threshold level established by Nunally (1972). In the case of the unsuccessful new development projects the fourth factor only included one variable "Existence of potential demand only (no actual market)". This is a very logical factor for the unsuccessful NPD projects.

In conclusion it can be said that the marketing managers in Finnish technology companies conceptualize the marketplace factors somewhat differently, and thus only partial equivalence exists between the managers' perceptions in successful and unsuccessful NPD projects. Thus hypothesis 2 is partially supported. Of the final set of market competitiveness variables in the EFA only the variables 'Competitors' frequently introduced new products", and "Our new product had a monopoly in the market" correlated with the NPD outcome. This is consistent with the Cooper and Kleinschmidt (1987) study according to which there appeared to be no relationship between market competitiveness and new product success. Of the final set of market attractiveness variables in the EFA all variables except the variable "Degree to which users' needs change quickly in the market" correlated with the NPD outcome. Again this is consistent with the Cooper and Kleinschmidt (1987) study according to which seven out of II measures of success correlated with market potential.

\section{Managerial Implications}

An important implication for managers of the high technology companies is that they face a much more fuzzy marketplace than those of more traditional companies. The most dominant factor worth paying attention to is the existence of competition. The issue here is not the competition as such, but rather the concern for competitors' activity regarding the introduction of new products into the marketplace. Consistently with Gardner et al. (2000) the price competition appears not to be the way to go regarding high technology products. Somewhat surprisingly the degree of satisfaction and loyalty with competitors' products appears not to be important either regarding the successful outcome of the high technology NPD project.

Complementing the importance of competition is striving for strong market position, maybe even a monopoly situation. Looking for unique market opportunities where customers have a high degree of unmet needs in the product class in question, and where the speed of acceptance of the new products is fast, is vital for high technology companies. Expectedly market size, existence of mass market, and market growth are important considerations. According to Rogers (1983) the speed of acceptance can be made faster by paying attention to the relative advantage the product offers, the compatibility of the product with existing values and past experiences of adopters, the complexity or difficulty of understanding how a new product works or how the consumer will recognize value, triability or the degree to which adopters can experiment with the product, and observability or the extent to which the results of the innovation can be seen by potential customers. Interestingly customers' changing needs appear not to be that critical regarding the successful outcome of the high technology NPD projects. This might be explained by the fact that in many cases the high technology products are so called "technology push" products, and thus not demanded by the customers in the first place (Herstatt and Letti, 2004; Trott, 200I).

\section{Conclusions}

This study was to a degree a replication of the Cooper (1979c) and Mishra et al. (1996) studies. The context of this exploratory study was, however, different, as well as 
the approach to compare the differences how managers conceptualize the marketplace. Partial equivalence was discovered in the managers' conceptualizations between successful and unsuccessful NPD projects. In addition, the managerial perceptions regarding the marketplace variables affecting the success between successful and unsuccessful NPD projects were compared. Multiple marketplace variables appeared to exist in affecting the success of NPD projects.

Clear factors appear to be the competitive environment as well as the large mass market. These two factors are also logical from the conceptual point of view. This research and the previous research indicate other factors/variables like customer need level for the product type, and importance of the product for the customer (Cooper, 1979a; Montoya-Weiss and Calantone, 1994; Song and Parry, 1997a; Yoon and Lilien, 1985; Zirger and Maidique, 1990). The overall conclusion is that the comparison of the factors/variables affecting the outcome of NPD projects in the case of the high technology companies should be done with caution because of only partial equivalence in the conceptualization of the marketplace factors is apparent.

\section{Limitations and Future Research}

This study like any other study has its' limitations. The comparison to the findings of other previously completed studies is always tricky, and should be approached with caution. This B2B study done with the Finnish technology companies is, however, in agreement with the previous research regarding the fact that the marketplace in the NPD context consists of multiple factors. Whether the results are applicable also in the business-to-consumer (B2C) setting is unknown, and thus more research is needed. The timing of this research can be as indicated as a potential reason for the differences in the managerial perceptions. The role of R\&D and the development of high technology products has been important for a long period of time in the Finnish economy, but it is still feasible that more current data than in this study could shed more light regarding the marketplace variables. Other potential reasons can be industry, culture and industrial development specific.

This research presents the results regarding the differences between marketplace variables in successful and unsuccessful NPD projects. In future research the factors discovered in this research could be tested with model building approach using the confirmatory factor analysis (CFA) (Hurley et al., 1997). In addition to the marketplace factors/variables also the managerial differences in the managerial conceptualizations regarding other relevant factors/variables should be investigated including compatibility of the new product with the company's current skills and resources, and the descriptors of the new product venture.

\section{References}

AHOLA, E. (2006), Secrets of Finnish competitiveness, Technology Innovation Center of Finland (Tekes). http://www.tekes.fi/eng/news/uutis tiedot.asp? id $=5250$

[Accessed 30 June 2008].

ANDERSON, J.C., Gerbing, D.W. (1988). Structural equation modeling in practice: $A$ review and recommended two-step approach. Psychological Bulletin, 103(3), 4I I-423.

BLUNDELL, R., Griffith, R., Van Reenen, J. (1999). Market share, market value and innovation in a panel of British manufacturing firms. Review of Economic Studies, 66(3), 529554.

BYRNE B. M., Watkins, D. (2003). The issue of measurement invariance revisited. Journal of Cross-Cultural Psychology, 34(2), I55-I75.

CAPON, N., Farley, J. U., Hoenig, S. (1990). Determinants of financial performance: A meta-analysis. Management Science, 36(10), II43-1159.

CHEUNG, M. W.-L., Chan, W. (2002). Reducing uniform response bias with ipsative measurement in multiple-group confirmatory factor analysis. Structural Equation Modeling, 9(I), 55-77.

CHURCHILL, G.A. Jr. and lacobucci, D. (2005). Marketing research: Methodological foundations. $9^{\text {th }}$ ed. Thomson, Ohio.

COOPER, R. G. (1979a). Identifying new product success and failure. Journal of Marketing, 8(2), I24-I35.

COOPER, R. G. (1979b). The dimensions of industrial product success and failure. Journal of Marketing, 43(3), 93103. 
COOPER, R. G. (1979c). Identifying new product success: The project NewProd. Industrial Marketing Management, $8(2), 124-135$.

COOPER, R. G. (1985). New product strategies: What distinguishes the top performer. Journal of Product Innovation Management, 2(3), I5I-164.

COOPER, R. G., Kleinschmidt, E. J. (1987). New products: What separates the winners from losers. Journal of Product Innovation Management, 4(3), 169-184.

COOPER, R. G., Kleinschmidt, E. J. (1995). Benchmarking the firms' critical success factors in new product development. Journal of Product Innovation Management, |2(5), 374-39|.

COSTELLO, A. B. Osborne, J. W. (2005). Best practices in exploratory factor analysis: Four recommendations for getting the most from your analysis. Practical Assessment Research \& Evaluation, 10(7), I-9.

DIEKHOFF, G. (1992). Statistics for the social and behavioral sciences: Univariate, bivariate, multivariate. $\mathrm{Wm}$ C. Brown Publishers, Dubuque, IA.

ERNST, H. (2002). Success factors of new product development: A Review of the Empirical Literature. International Journal of Management Reviews, 4(I), I-40.

GARDNER, D.M., Johnson, F., Lee, M., Wilkinson, I. (2000). A contingency approach to marketing high technology products. European Journal of Marketing, 34(9/10), 1053-1077.

HAIR, J. F., Black, B.C., Babin, B. J., Anderson. R. E., Tatham, R. L. (2006). Multivariate data analysis. 6th edition. Pearson International Edition.

HAVERILA, M. (2009). The factors affecting new product success in technology companies: Case Finland. International Journal of Product Management, 12(2), 176-198.

HECK, R.H. (1988). Factor analysis: Exploratory and confirmatory approaches. In: Marcoulides, G.A. (Ed.), Modern methods for business research, Lawrence Erlbaum Associates, Hillsdale, II7-2I5.
HENARD, D. H., Szymanski, D. M. (200I). Why some new products are more successful than others. Journal of Marketing Research, 38(3), 362-375.

HERSTATT, C., Lettl, C. (2004). Management of "technology push" development projects. International Journal of Technology Management, 27(2-3), 155 - 175

HOFFMAN, K., Parejoa, M., John Bessant, J., Perrena, L. (1998). Small firms, R\&D, technology and innovation in the UK: A literature review. Technovation, I8(I), 39-55.

HURLEY, A. J., Scandura, T. A., Schriesheim, C.A., Brannick, M.T., Sears, A., Vandenberg, R.J., Williams, L.J. (1997). Exploratory and confirmatory factor analysis: Guidelines, issues, and alternatives. Journal of Organizational Behavior, 18(6), 667-683.

JIANG, Z., Zeyuan. L., Wei, Z. (2006). Dynamic model of knowledge growth of the OECD Countries and knowledge capacities measuring, Dynamic model of knowledge growth of the OECD Countries and knowledge capacities measuring. In: Proceedings International Workshop on Webometrics, Informetrics and Scientometrics, Seventh COLLNET Meeting, Nancy (France).

KIM, J., Mueller, C.W. (1978). Factor analysis: Statistical methods and practical issues. Sage, Beverly Hills, CA.

MISHRA, S., Kim, D., Hoon Lee, D. (1996). Factors affecting new products success: Cross-country comparisons. Journal of Product Innovation Management, 13(6), 530-550.

MOHNEN, P. (2005). The importance of R\&D: Is the Barcelona $3 \%$ a reasonable target? http://www.unimaas.nl/bestand.asp?id=3826 [Accessed 30 June 2008].

MOHR, J. M. (1996). The management and control of information in high-technology firms. Journal of High Technology Management Research, 7(2), 245-268.

MOHR, J. M., Sengupta, S., Slater, S. F. (2004). Marketing of high-technology products and innovations. Pearson Education. 
MONTOYA-WEISS, M., Calantone, R. (1994). Determinants of new product performance: $A$ review and meta-analysis. Journal of Product Innovation Management, II (5), 397-4I7.

MYERS, S., Marquis, D. G. (1969). Successful industrial innovations. National Science Foundation, NSF 69-17.

NUNNALLY, J.C. (1972). Educational measurement and evaluation. 2nd ed., McGraw-Hill, New York, NY.

OECD Factbook 2005. High-technology exports. http://www.oecd.org/dataoecd/42/28/34416149.pdf

[Accessed 20 March 2010].

ROBERTS, R.W., Burke, J.E. (1974). Six new products What made them successful. Research Management, 16(3), 2I-24.

ROGERS, E.M. (1983). Diffusion of Innovations. 3rd ed.The Free Press, New York.

SONG, X. M., Parry, M. E. (1997a). A cross-national comparative study of new product development processes: Japan and the United States", Journal of Marketing, 6I (2), I18.

SONG, X. M., Parry, M. E. (1997b). The determinants of Japanese new product success. Journal of Marketing Research, 3I(I), 64-76.

STREINER, D. L., Norman, G. R. (1989). Health measurement scales: A practical guide to their development and use. Oxford University Press, New York.

TABACHNICK, B.G., Fidell, L.S. (200I). Using multivariate statistics. 4th ed. Allyn and Bacon, Needham Heights, MA.

TROTT, P. (200I). The role of market research in the development of discontinuous new products. European Journal of Innovation Management, 4(3), I I7-126.

URBAN, G. L., Hauser, J. R. (1993). Design and marketing of new products. $2^{\text {nd }}$ ed., Prentice Hall, Upper Saddle River, New Jersey.

WANG, Z. (2007). Technological innovation and market turbulence: The dot-com experience. Review of Economic Dynamics, 10(I), 78-105.
YOON, E., Lilien, G. L. (1985). New industrial product performance: The effects of market characteristics and strategy. Journal of Product Innovation Management, 2(3), |34-| 44.

ZIRGER, B. J., Maidique, M. A. (1990). A model of new product development: An empirical test. Management Science, 36(7), 867-883. 
1. Competitors' intro of new products

2. Existence of dominant competitor

3. Price competition

4. Satisfaction with competitors' products

5. Degree of loyalty to competitors' products

6. New product had monopoly in market

7. Degree of

competition

8. Existence of

potential demand only

9. Users' needs' change quickly

10. Government role of in marketplace

11. Market size

12. Existence of mass market

13. Need for products in product class

\section{Market growth}

15. Favorable global economic situation

16. Acceptance of new product

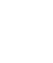

2

4

5

6

7

10

11

12

13

14

15

16 Mean

Std.

$4.02 \quad 1.38$

0.27

$(0.00)^{* *}$

0.16

0.57
$(0.00)^{* *}$

$(0.00)^{* *} \quad 1$

0.15

$\begin{array}{cc}0.42 & 0.28 \\ (0.00)^{* *} & (0.00)^{* *}\end{array}$

$\begin{array}{cccc}0.07 & 0.45 & 0.41 & 0.58 \\ & (0.00)^{* *} & (0.00)^{* *} & (0.00)^{* *}\end{array}$

1

$\begin{array}{llllll}-0.06 & 0.15 & -0.05 & 0.15 & 0.07 & 1\end{array}$

$4.48 \quad 1.55$

$4.40 \quad 1.57$

$4.43 \quad 1.53$

$4.21 \quad 1.31$

$5.72 \quad 1.25$

$3.73 \quad 1.46$

$3.86 \quad 2.09$

$4.89 \quad 1.47$

$4.42 \quad 2.16$

$4.98 \quad 1.34$

$5.04 \quad 1.34$

$5.57 \quad 1.12$

$4.62 \quad 1.48$

$4.49 \quad 1.57$

$0.11 \quad 0.06$

$(0.05)^{*} \quad 0.02$

$\begin{array}{ccc}0.29 & 0.30 & 0.35 \\ (0.00)^{* *} & (0.00)^{* *} & (0.00)^{* *}\end{array}$

$\begin{array}{ccc}0.31 & 0.28 & 0.35 \\ (0.00)^{* *} & (0.00)^{* *} & (0.00)^{* *}\end{array}$

$\begin{array}{lllcc}0.03 & 0.15 & 0.09 & 0.22 & 0.36 \\ (0.00)^{* *} & (0.00)^{* *}\end{array}$

$5.30 \quad 1.42$

Table 3. Correlation coefficients and $p$-values of variables in successful NPD projects $(*) p<0.05 * *) p<0.01$ )

ISSN: 07|8-2724. (http://www.jotmi.org) 


\begin{tabular}{|c|c|c|c|c|c|c|c|c|c|c|c|c|c|c|c|c|c|c|}
\hline Variable & 1 & 2 & 3 & 4 & 5 & 6 & 7 & 8 & 9 & 10 & 11 & 12 & 13 & 14 & 15 & 16 & Mean & $\begin{array}{l}\text { Std. } \\
\text { dev. }\end{array}$ \\
\hline $\begin{array}{l}\text { 1. Competitors' intro } \\
\text { of new products }\end{array}$ & 1.00 & & & & & & & & & & & & & & & & 3.47 & 1.48 \\
\hline $\begin{array}{l}\text { 2. Existence of } \\
\text { dominant competitor }\end{array}$ & $\begin{array}{c}0.40 \\
(0.00)^{* *}\end{array}$ & 1.00 & & & & & & & & & & & & & & & 4.29 & 1.72 \\
\hline 3. Price competition & $\begin{array}{c}0.38 \\
(0.00)^{* *}\end{array}$ & $\begin{array}{c}0.55 \\
(0.00)^{* *}\end{array}$ & 1.00 & & & & & & & & & & & & & & 4.52 & 1.66 \\
\hline $\begin{array}{l}\text { 4. Satisfaction with } \\
\text { competitors' products }\end{array}$ & $\begin{array}{c}0.31 \\
(0.00)^{* *}\end{array}$ & $\begin{array}{c}0.38 \\
(0.00)^{* *}\end{array}$ & $\begin{array}{c}0.32 \\
(0.00)^{* *}\end{array}$ & 1.00 & & & & & & & & & & & & & 4.50 & 1.53 \\
\hline $\begin{array}{l}\text { 5. Degree of loyalty to } \\
\text { competitors' products }\end{array}$ & $\begin{array}{c}0.37 \\
(0.00)^{* *}\end{array}$ & $\begin{array}{c}0.46 \\
(0.00)^{* *}\end{array}$ & $\begin{array}{c}0.45 \\
(0.00)^{* *}\end{array}$ & $\begin{array}{c}0.62 \\
(0.00)^{* *}\end{array}$ & 1.00 & & & & & & & & & & & & 4.49 & 1.42 \\
\hline $\begin{array}{l}\text { 6. New product had } \\
\text { monopoly in market }\end{array}$ & $\begin{array}{c}0.27 \\
(0.00)^{* *}\end{array}$ & $\begin{array}{c}0.29 \\
(0.00)^{* *}\end{array}$ & $\begin{array}{c}0.15 \\
(0.05)^{*}\end{array}$ & 0.06 & $\begin{array}{c}0.24 \\
(0.00)^{* *}\end{array}$ & 1.00 & & & & & & & & & & & 3.60 & 1.73 \\
\hline $\begin{array}{l}\text { 7. Degree of } \\
\text { competition }\end{array}$ & $\begin{array}{c}0.23 \\
(0.00)^{* *}\end{array}$ & $\begin{array}{c}0.17 \\
(0.05)^{*}\end{array}$ & $\begin{array}{c}0.27 \\
(0.00)^{* *}\end{array}$ & $\begin{array}{c}0.32 \\
(0.00)^{* *}\end{array}$ & 0.21 & 0.14 & 1.00 & & & & & & & & & & 3.57 & 1.59 \\
\hline $\begin{array}{l}\text { 8. Existence of } \\
\text { potential demand only }\end{array}$ & 0.03 & $\begin{array}{c}-0.17 \\
(0.05)^{*}\end{array}$ & -0.16 & $\begin{array}{c}-0.26 \\
(0.00)^{* *}\end{array}$ & $\begin{array}{c}-0.23 \\
(0.00)^{* *}\end{array}$ & 0.10 & -0.03 & 1.00 & & & & & & & & & 2.52 & 1.48 \\
\hline $\begin{array}{l}\text { 9. Users’ needs’ } \\
\text { change quickly }\end{array}$ & $\begin{array}{c}0.28 \\
(0.00)^{* *}\end{array}$ & $\begin{array}{c}0.59 \\
(0.00)^{* *}\end{array}$ & $\begin{array}{c}0.58 \\
(0.00)^{* *}\end{array}$ & $\begin{array}{c}0.44 \\
(0.00)^{* *}\end{array}$ & $\begin{array}{c}0.48 \\
(0.00)^{* *}\end{array}$ & $\begin{array}{c}0.25 \\
(0.00)^{* *}\end{array}$ & 0.18 & $\begin{array}{c}-0.31 \\
(0.00)^{* *}\end{array}$ & 1.00 & & & & & & & & 4.73 & 1.68 \\
\hline $\begin{array}{l}\text { 10. Government role } \\
\text { of in marketplace }\end{array}$ & -0.05 & 0.07 & 0.10 & 0.02 & 0.08 & -0.03 & $\begin{array}{c}-0.28 \\
(0.00)^{* *}\end{array}$ & -0.09 & 0.15 & 1.00 & & & & & & & 4.22 & 2.16 \\
\hline 11. Market size & 0.11 & $\begin{array}{c}0.41 \\
(0.00)^{* *}\end{array}$ & 0.16 & 0.10 & $\begin{array}{c}0.22 \\
(0.00)^{* *}\end{array}$ & $\begin{array}{c}0.36 \\
(0.00)^{* *}\end{array}$ & 0.09 & -0.01 & $\begin{array}{c}0.31 \\
(0.00)^{* *}\end{array}$ & 0.15 & 1.00 & & & & & & 3.67 & 1.50 \\
\hline $\begin{array}{l}\text { 12. Existence of mass } \\
\text { market }\end{array}$ & 0.12 & $\begin{array}{c}0.27 \\
(0.00)^{* *}\end{array}$ & 0.09 & 0.11 & 0.15 & $\begin{array}{c}0.52 \\
(0.00)^{* *}\end{array}$ & 0.04 & 0.03 & $\begin{array}{c}0.27 \\
(0.00)^{* *}\end{array}$ & 0.11 & $\begin{array}{c}0.62 \\
(0.00)^{* *}\end{array}$ & 1.00 & & & & & 3.53 & 1.46 \\
\hline $\begin{array}{l}\text { 13. Need for products } \\
\text { in product class }\end{array}$ & 0.23 & $\begin{array}{c}0.30 \\
(0.00)^{* *}\end{array}$ & $\begin{array}{c}0.24 \\
(0.00)^{* *}\end{array}$ & 0.11 & 0.11 & $\begin{array}{c}0.44 \\
(0.00)^{* *}\end{array}$ & $\begin{array}{c}0.20 \\
(0.05)^{*}\end{array}$ & -0.05 & $\begin{array}{c}0.28 \\
(0.00)^{* *}\end{array}$ & 0.09 & $\begin{array}{c}0.54 \\
(0.00)^{* *}\end{array}$ & $\begin{array}{c}0.55 \\
(0.00)^{* *}\end{array}$ & 1.00 & & & & 3.44 & 1.53 \\
\hline 14. Market growth & $\begin{array}{c}0.17 \\
(0.05)^{*}\end{array}$ & 0.06 & 0.00 & 0.04 & -0.03 & $\begin{array}{c}0.31 \\
(0.00)^{* *}\end{array}$ & $\begin{array}{c}0.27 \\
(0.00)^{* *}\end{array}$ & 0.04 & 0.03 & -0.02 & $\begin{array}{c}0.27 \\
(0.00)^{* *}\end{array}$ & $\begin{array}{c}0.33 \\
(0.00)^{* *}\end{array}$ & $\begin{array}{c}0.49 \\
(0.00)^{* *}\end{array}$ & 1.00 & & & 3.26 & 1.35 \\
\hline $\begin{array}{l}\text { 15. Favorable global } \\
\text { economic situation }\end{array}$ & 0.09 & 0.06 & 0.01 & 0.15 & -0.01 & 0.08 & -0.01 & 0.03 & 0.01 & 0.14 & 0.09 & $\begin{array}{c}0.18 \\
(0.05)^{*}\end{array}$ & $\begin{array}{c}0.27 \\
(0.00)^{* *}\end{array}$ & $\begin{array}{c}0.24 \\
(0.00)^{* *}\end{array}$ & 1.00 & & 3.21 & 1.35 \\
\hline $\begin{array}{l}\text { 16. Acceptance of } \\
\text { new product }\end{array}$ & $\begin{array}{c}0.24 \\
(0.00)^{* *}\end{array}$ & 0.00 & 0.04 & 0.09 & 0.05 & $\begin{array}{c}0.27 \\
(0.00)^{* *}\end{array}$ & $\begin{array}{c}0.24 \\
(0.00)^{* *}\end{array}$ & 0.05 & 0.01 & -0.12 & $\begin{array}{c}0.20 \\
(0.05)^{*}\end{array}$ & $\begin{array}{c}0.27 \\
(0.00)^{* *}\end{array}$ & $\begin{array}{c}0.43 \\
(0.00)^{* *}\end{array}$ & $\begin{array}{c}0.48 \\
(0.00)^{* *}\end{array}$ & $\begin{array}{c}0.17 \\
(0.05)^{*}\end{array}$ & 1.00 & 2.82 & 1.49 \\
\hline
\end{tabular}

